\title{
HUBUNGAN PASCA PEMAKAIAN KONTRASEPSI HORMONAL DENGAN KESUBURAN PADA IBU HAMIL
}

\author{
Wiwin Hindriyawati ${ }^{1)}$, Widy Nurwiandani ${ }^{2)}$ \\ ${ }^{1-2}$ STIKes AKBIDYO Yogyakarta \\ e-mail:winwin.f815@gmail.com
}

\begin{abstract}
ABSTRAK
Kontrasepsi hormonal merupakan kontrasepsi yang diminati masyarakat. Kontrasepsi hormonal progestin terdiri dari $\mathrm{KB}$ suntik 3 bulan dan implant, kontrasepsi hormonal jenis kombinasi berisi estrogen dan progestin terdiri dari KB suntik 1 bulan. Persepsi masyarakat menganggap kontrasepsi hormonal dapat membuat seseorang mengalami gangguan kesuburan. Tujuan penelitian untuk mengidentifikasi hubungan pasca pemakaian kontrasepsi hormonal dengan kesuburan pada ibu hamil. Metode penelitian menggunakan deskriptif correlation dengan pendekatan retrospektif dengan rancangan cross sectional. Uji statistik bivariat menggunakan kendall's tau. Populasi ibu hamil yang pernah menggunakan kontrasepsi hormonal di Desa Guwosari pada bulan November 2019-Januari 2020. Sampel penelitian 64 responden diambil dengan teknik purposive sampling. Hasil penelitian menunjukkan terdapat hubungan bermakna pasca pemakaian kontrasepsi hormonal dengan kesuburan pada ibu hamil (perolehan menstruasi $p$-value 0,003; perolehan kehamilan p-value 0,011). Kesimpulan penelitian terdapat hubungan bermakna pasca pemakaian kontrasepsi hormonal dengan kesuburan pada ibu hamil.
\end{abstract}

Kata kunci: kesuburan; pasca kontrasepsi hormonal

\section{ABSTRACT}

People tend to use hormonal contraceptives. Progestin hormonal contraceptives consist of 3-month injectable contraceptives and implants, combined hormonal contraceptives contain estrogen and progestin consisting of 1-month injections. People have perception considers hormonal contraception that can make a woman experience fertility problem. The aim of the study was to identify the relationship between post-hormonal contraceptive use and fertility in pregnant women. The research method was using descriptive correlation with a retrospective approach with a cross sectional design. Bivariate statistical test was using Kendall's tau. The population were pregnant women who have used hormonal contraception in Guwosari Village in November 2019-January 2020. The research sample of 64 respondents were taken using a purposive sampling technique. The result showed that there was a significant relationship after using hormonal contraception with fertility in pregnant women (menstrual gain p-value 0.003; pregnancy gain p-value 0.011). The conclusion of the study was there is a significant relationship after the use of hormonal contraception with fertility in pregnant women.

Keywords: fertility; post hormonal contraception

\section{PENDAHULUAN}

Salah satu metode kontrasepsi modern adalah kontrasepsi hormonal. Kontrasepsi hormonal adalah alat atau obat kontrasepsi yang bertujuan untuk mencegah terjadinya kehamilan dengan menggunakan bahan baku preparat estrogen-progesteron ataupun progesteron saja (Hartanto 2010). Data Kabupaten Bantul menunjukkan mayoritas masyarakat menggunakan alat KB hormonal menggunakan suntik sebanyak 3.815 orang $(45,54 \%)$ yang disusul kemudian dengan KB non hormonal IUD sebanyak 2.451 orang $(29,26 \%)$ (DIY BPS, 2020).

Secara umum persyaratan metode kontrasepsi yang ideal adalah aman, artinya tidak akan menimbulkan komplikasi berat bila digunakan; berdaya guna, dalam arti bila digunakan sesuai dengan aturan akan dapat mencegah terjadinya kehamilan; dapat diterima, bukan hanya oleh klien melainkan juga oleh lingkungan budaya di masyarakat; terjangkau harganya oleh masyarakat; bila metode tersebut dihentikan penggunaanya, klien akan segera kembali kesuburannya, kecuali untuk kontrasepsi mantap (Saifuddin, 2010).

Salah satu hal yang perlu mendapat perhatian setelah penggunaan suatu kontrasepsi adalah saat kesuburannya kembali lagi. Kecuali metode sterilisasi laki-laki dan perempuan, penggunaan 
metode kontrasepsi tidak menyebabkan perubahan kesuburan yang ireversibel. Kesuburan segera kembali pada semua metode, kecuali Depot Medroxyprogesterone Acetate (DMPA) dan Noretisteron Enentat (NETEN). Ratarata waktu kembalinya kesuburan pada kedua metode tersebut masing-masing adalah 10 dan 6 bulan dari suntikan terakhir, tanpa memandang lama penggunaan. Sterilisasi pria dan wanita merupakan metode permanen sehingga setiap orang maupun pasangan yang ingin memilih metode ini perlu diberi konsultasi. Tidak ada metode lain yang menyebabkan infertilitas permanen (Sumadikarya, 2009).

Adanya anggapan yang keliru pada masyarakat bahwa kontrasepsi tertentu menyebabkan seseorang menjadi sulit hamil. Banyak wanita yang mengeluh jadi sulit hamil setelah berhenti menggunakan KB (Anna, 2016).

Berdasarkan studi pendahuluan bulan Januari 2019 di Desa Guwosari dari 288 pasangan usia subur yang ikut KB $198 \mathrm{KK}$, dan terdapat ibu hamil sebanyak $120 \mathrm{ibu}$, Pil 15 KK, Kondom 12 KK, IUD 68 KK,
Suntik $68 \mathrm{KK}$, implant $3 \mathrm{KK}$, MOP $1 \mathrm{KK}$, MOW $10 \mathrm{KK}$. Penelitian ini bertujuan untuk mengidentifikasi hubungan pasca pemakaian kontrasepsi hormonal dengan kesuburan pada ibu hamil.

\section{METODOLOGI PENELITIAN}

Penelitian ini menggunakan desain descriptive corellation dengan pendekatan retrospektif dengan rancangan cross sectional (Arikunto, 2010). Populasi ibu hamil yang pernah menggunakan kontrasepsi hormonal di Desa Guwosari pada bulan November 2019 - Januari 2020. Sampel penelitian ini adalah 64 ibu hamil yang terdiri dari 32 ibu hamil pasca pemakaian kontrasepsi hormonal kombinasi (Estrogen-Progesteron) dan 32 ibu hamil pasca pemakaian kontrasepsi progestin. Metode yang digunakan adalah purposive sampling dengan cara mendatangi rumah yang sesuai dengan kriteria, maka sampel tersebut diambil dan diberikan informed consent. Jika setuju maka dijadikan sebagai sampel penelitian. Uji analisis bivariat menggunakan kendall's tau.

\section{HASIL}

a. Karakteristik Responden.

Tabel. 1. Distribusi Karakteristik Responden

\begin{tabular}{lcc}
\hline Usia & f & $\%$ \\
\hline Reproduksi Sehat (20-35 Th) & 48 & 75,0 \\
Reproduksi Tua (> 35 Th) & 16 & 25,0 \\
Total & 64 & 100 \\
\hline Pendidikan & & \\
\hline SD-SMP & 39 & 60,9 \\
SMA/SMK & 25 & 32,8 \\
Total & 64 & 100 \\
\hline Pekerjaan & & \\
\hline IRT & 37 & 57,8 \\
Swasta & 21 & 32,8 \\
Wiraswasta & 6 & 9,4 \\
Total & 64 & 100 \\
\hline Riwayat Kontrasepsi Hormonal & & 50 \\
\hline Hormonal Progestin & 32 & 50 \\
Hormonal Progestin-Estrogen & 32 & 100 \\
Total & 64 & \\
\hline
\end{tabular}

Hasil data distribusi karakteristik responden paling banyak pada usia reproduksi sehat (20-35 tahun) $75 \%$, pendidikan SD-SMP sebanyak 60,9\%, pekerjaan sebagai IRT 57,8\%, dan riwayat kontrasepsi hormonal progestin dan estrogen-progestin masing-masing $50 \%$.

b. Analisis Univariat

Tabel 2. Distribusi Frekuensi Berdasarkan Jenis Kontrasepsi Hormonal dan Kesuburan 


\begin{tabular}{lcc}
\hline Jenis Kontrasepsi Hormonal & $\mathrm{f}$ & $\%$ \\
\hline Progestin & 32 & 50 \\
Kombinasi (Estrogen-Progestin) & 32 & 50 \\
Total & 100 & 100 \\
\hline Kesuburan (Perolehan Menstruasi) & & \\
\hline$<6$ Bulan & 56 & 87,5 \\
$\geq 7$ Bulan & 8 & 12,5 \\
Total & 64 & 100,0 \\
\hline Kesuburan (Perolehan Kehamilan) & & \\
\hline Cepat $(0-2$ Th) & 58 & 70,6 \\
Cukup (3-6 Th) & 5 & 1,6 \\
Lambat $(\geq 7$ th) & 1 & 100 \\
Total & 64 & \\
\hline
\end{tabular}

Hasil data distribusi univariat jenis kontrasepsi hormonal progestin dan estrogen-progestin masing-masing 50\%, perolehan menstruasi paling banyak pada waktu $<6$ bulan sebanyak $87,5 \%$, dan perolehan kehamilan paling banyak dengan waktu cepat $(0-2$ tahun $)$ sebanyak $90,6 \%$.

c. Analisis Bivariat

a. Analisis Hubungan Pasca Kontrasepsi Hormonal dengan Perolehan Menstruasi

Tabel 3. Hasil Uji Kendall's Tau Hubungan Pasca Kontrasepsi Hormonal dengan Perolehan Menstruasi

\begin{tabular}{lll}
\hline & Perolehan Menstruasi & \\
\hline Kontrasepsi Hormonal & $p$-value & 0,003 \\
\hline
\end{tabular}

b. Analisis Hubungan Pasca Kontrasepsi Hormonal dengan Perolehan Kehamilan

Tabel 4. Hasil Uji Kendall's Tau Hubungan Pasca Kontrasepsi Hormonal dengan Perolehan Kehamilan

\begin{tabular}{lll}
\hline & Perolehan Kehamilan & \\
\hline Kontrasepsi Hormonal & p-value & 0,011 \\
\hline
\end{tabular}

c. Tabulasi silang Pasca Kontrasepsi Hormonal dengan Perolehan Menstruasi

Tabel 5. Tabulasi silang Pasca Kontrasepsi Hormonal dengan Perolehan Menstruasi

\begin{tabular}{lccc}
\hline Pasca Kontrasepsi & \multicolumn{2}{c}{ Perolehan Menstruasi } & Rata-Rata/bulan \\
\cline { 2 - 3 } Hormonal & $\leq 6$ bulan & $\geq 7$ bulan & \\
\hline Progesteron & 24 & 8 & 8,187 \\
\hline $\begin{array}{l}\text { Kombinasi } \\
\text { (Progesteron-Estrogen) }\end{array}$ & 32 & 0 & 2,031 \\
\hline Total & 56 & 8 & \\
\hline
\end{tabular}

Hasil menunjukkan kontrasepsi seluruhnya kembali menstruasi $<6$ hormonal kombinasi (Progesteronbulan.

Estrogen) sebanyak 32 responden,

d. Tabulasi Silang Pasca Kontrasepsi Hormonal Dengan Perolehan Kehamilan Tabel 6. Tabulasi silang pasca kontrasepsi hormonal dengan perolehan kehamilan

\begin{tabular}{|c|c|c|c|c|}
\hline \multirow{2}{*}{$\begin{array}{l}\text { Pasca } \\
\text { Hormonal }\end{array}$} & \multicolumn{3}{|c|}{ Perolehan Kehamilan } & \multirow{2}{*}{$\begin{array}{c}\text { Rata- } \\
\text { Rata/bulan }\end{array}$} \\
\hline & 0-2 Tahun & 3-5 Tahun & $\geq 6$ Tahun & \\
\hline Progesteron & 26 & 5 & 1 & 10 \\
\hline $\begin{array}{l}\text { Kombinasi } \\
\text { (Progesteron-Estrogen) }\end{array}$ & 32 & 0 & 0 & 19,656 \\
\hline Total & 58 & 5 & 1 & \\
\hline
\end{tabular}


Hasil menunjukkan kontrasepsi hormonal kombinasi (ProgesteronEstrogen) sebanyak 32 responden, seluruh responden dengan Perolehan Kehamilan dengan waktu $0-2$ tahun.

\section{PEMBAHASAN}

a. Hubungan Pasca Kontrasepsi Hormonal dengan Perolehan Menstruasi

Hasil penelitian menunjukkan $p$-value 0,003 sehingga terdapat hubungan pasca kontrasepsi hormonal dengan perolehan menstruasi. Berdasarkan teori Siswosudarmo (2007) bahwa pada Wanita umur 20 - 35 tahun merupakan periode reproduksi sehat. Periode ini merupakan masa yang tepat untuk bereproduksi sebab tidak mempunyai risiko tinggi dalam proses kehamilan dan persalinan. Sedangkan usia 36 - 45 tahun merupakan kurun reproduksi tua karena merupakan periode usia yang termasuk dalam usia risiko tinggi dalam kehamilan dan persalinan. Pada penelitian ini didapatkan bahwa sebagian besar responden $(75 \%)$ berada pada kurun reproduksi sehat yaitu usia 20-35 tahun sedangkan $(25 \%)$ responden berada pada kurun reproduksi tua.

Penggunaan alat kontrasepsi hormonal seperti suntik, pil, dan implan pada fase menjarangkan kehamilan adalah cara KB yang efektif. Hasil penelitian terdapat hubungan pasca kontrasepsi hormonal dengan perolehan menstruasi dengan nilai p-value 0,003 .

Salah satu keuntungan penggunaan kontrasepsi hormonal segera mendapatkan kesuburan kembali (cepat mendapatkan menstruasi dan kehamilan). Pasca penggunaan kontrasepsi hormonal akan terjadi kesuburan dengan mendapatkan menstruasi kembali. Menurut teori Hartanto (2010) penggunaan kontrasepsi suntik 1 bulan (Kombinasi/Progesteron-Estrogen) berbeda dengan kontrasepsi progestin salah satunya suntik 3 bulan akan berpengaruh terhadap lama kembalinya menstruasi. Pada hasil penelitian rata-rata kembali kesuburan dengan perolehan menstruasi pada kontrasepsi kombinasi membutuhkan waktu 2, 031 bulan, dan kontrasepsi progestin membutuhkan waktu 8,187 bulan untuk mendapatkan menstruasi kembali. Hal ini dikarenakan kontrasepsi kombinasi lebih mudah dimetabolisme oleh tubuh dibandingkan hormonal progestin. Setelah semua hormon dimetabolisme maka kesuburan dengan perolehan menstruasi akan segera didapatkan.

Dilihat dari cara kerja kontrasepsi hormonal yang berisi progestin salah satu mekanisme kerjanya dengan menghambat perkembangan folikel dan ovulasi. Umpan balik negatif progestin pada hipotalamus menghambat Gonadotropin-Releasing Hormone (GnRH), yang mengurangi pelepasan Follicle-Stimulating Hormone (FSH) dan Luteinizing Hormone (LH) oleh hipofise anterior. Menurunnya kadar FSH menyebabkan hambatan pada perkembangan folikel, mencegah meningkatnya kadar estradiol. Umpan balik negatif ini dan kurangnya umpan balik estrogen positif pada pelepasan $\mathrm{LH}$ mencegah lonjakan LH yang mencegah ovulasi. Kontrasepsi hormonal progestin juga mengentalkan lendir serviks dan menipiskan lapisan endometrium dan menyebabkan perubahan motilitas tuba (Whitaker \& Gilliam, 2014).

Metode kontrasepsi hormonal juga memiliki kandungan estrogen (kombinasi) yang berkontribusi terhadap penghambatan ovulasi tetapi fungsi utamanya untuk mengatur perdarahan sehingga dapat terjadi sesuai jadwal dan dengan interval yang teratur. Bahkan meskipun dengan penambahan estrogen, efek progestin pada endometrium tetap dipertahankan (penipisan endometrium atau atrofi (Blumenthal \& Edelman, 2008) Paparan estradiol selama fase folikuler bertanggung jawab atas proliferasi endometrium. Paparan progesteron pada fase luteal menghasilkan diferensiasi sekresi. Progesteron adalah antiestrogenik dan menghambat pertumbuhan endometrium dan diferensiasi kelenjar. Tanpa terjadinya kehamilan dapat memicu timbulnya perdarahan menstruasi. Pemberian hormon secara eksogen, dalam bentuk kontrasepsi hormonal, secara dramatis mempengaruhi histologi endometrium. Mekanisme terjadinya masalah perdarahan terkait dengan kontrasepsi hormonal sebagian besar tidak dapat dijelaskan. Seorang wanita yang menggunakan kontrasepsi kombinasi (estrogen dan progesteron) mungkin dapat mengalami waktu menstruasi yang lebih pendek atau lebih singkat (Noviawati, 2011). Sesuai dengan penelitian (Adiesti \& Wari, 2020) 
kontrasepsi hormonal progestin berhubungan dengan siklus menstruasi dan memiliki resiko 1,6 kali lebih besar dibandingkan kontrasepsi hormonal kombinasi, dari siklus spotting sampai dengan amenorea. Hal ini bisa menyebabkan kembali menstruasi pada kontrasepsi progestin membutuhkan waktu lebih lama dibandingkan kontrasepsi progesteron.

Menurut literatur (Saifuddin, et al., 2010) bahwa keuntungan setelah berhenti menggunakan kontrasepsi hormonal yaitu mengembalikan kesuburan dengan cepat. Kontrasepsi hormonal (suntik dan pil baik progestin maupun kombinasi dan implant) menyebabkan kesuburan cepat kembali (perolehan menstruasi dan kehamilan) (Anna, 2016).

b. Hubungan Pasca Kontrasepsi Hormonal dengan Perolehan Kehamilan

Berdasarkan uji statistik diperoleh $p$ value 0,011 berarti ada hubungan pasca kontrasepsi hormonal dengan perolehan kehamilan. Proses kehamilan dimulai dari proses ovulasi, konsepsi, hingga implantasi dalam rahim. Ovulasi terjadi ketika sel telur (ovum) keluar dari ovarium. Ovulasi ini normalnya terjadi setiap bulan sesuai siklus menstruasi dan rata- rata terjadi sekitar dua minggu sebelum periode (siklus) menstruasi berikutnya. Kenaikan hormon setelah telur meninggalkan folikel yang kemudian berkembang menjadi sesuatu yang disebut korpus luteum. Korpus luteum melepaskan hormon yang membantu menebalkan lapisan rahim, untuk mempersiapkan ketika terjadi proses kehamilan nantinya. Sel telur dilepaskan dan bergerak ke tuba falopi dan menetap selama 24 jam untuk menunggu sel sperma untuk membuahi. Proses ini rata-rata terjadi selama dua minggu dimulai setelah hari pertama menstruasi terakhir (Prawirohardjo, 2016). Sejalan dengan penelitian (Harni \& Anita, 2017) bahwa ada perbedaan bermakna antara $\mathrm{KB}$ suntik 1 bulan (Progesteron-Estrogen) dan KB suntik 3 bulan (Progestin).

Rata-rata waktu perolehan kehamilan pada kontrasepsi kombinasi lebih cepat dibandingkan kontrasepsi progestin didapatkan hasil hormonal kombinasi selama 10 bulan, sedangkan hormonal progestin selama 19,656 bulan. Hal ini sejalan dengan penelitian (Agustin et al.,
2016) ada perbedaan kesuburan kembali pada kontrasepsi suntik, dimana pada kontrasepsi suntik progestin membutuhkan waktu yang lama 4 - 10 bulan, bahkan ada beberapa wanita yang sampai bertahuntahun tidak hamil. Kontrasepsi hormonal khususnya suntik 3 bulan (Progesteron) yang cukup lama akan mempengaruhi proses pengembalian keseimbangan hormonal dan menyebabkan proses kehamilan akan berjalan lambat untuk beberapa waktu, meskipun telah berhenti menggunakan kontrasepsi tersebut. Hal tersebut dikarenakan penggunaan progestin akan mengakibatkan pembentukan Luteinizing Hormon Relasing Factor (LHRF) dan Folicle Stimulating Hormone Relasing (FSHRF) yang dapat mengubah lendir serviks menjadi kental, dan tidak dapat berhenti dengan cepat dikarenakan kembalinya perubahan hormon akan lebih lambat jika dibandingkan KB 1 bulan atau KB kombinasi (Fahira, 2014).

Berdasarkan hasil tabulasi silang didapatkan rata-rata waktu tunggu pasca kontrasepsi hormonal dengan perolehan kehamilan pada progestin 19,656 bulan dan kombinasi 10 bulan. Responden yang mendominasi pada penelitian ini usia reproduksi sehat 20-35 tahun sebanyak $75 \%$ dengan lama waktu tunggu hamil kategori cepat $0-2$ tahun. Berdasarkan teori (Siswosudarmo, 2007) bahwa pada umur 20 - 35 tahun merupakan masa reproduksi sehat, sebab tidak berisiko tinggi mengalami gangguan selama proses kehamilan dan persalinan. Sedangkan usia 36 - 45 tahun merupakan masa reproduksi tua, karena usia risiko tinggi. Pemilihan alat kontrasepsi hendaknya disesuaikan dengan tahap masa reproduksi tersebut. Perolehan kehamilan dengan waktu tunggu lama $>6$ tahun, bukan disebabkan oleh penggunaan kontrasepsi hormonal. Hal tersebut sesuai dengan penelitian bahwa tidak ada hubungan lama penggunaan kontrasepsi hormonal dengan perolehan kehamilan (Aldriana, 2017). Faktor penyebab sulit hamil setelah pemakaian $\mathrm{KB}$ berkaitan dengan usia, paritas (jumlah persalinan sebelumnya), dan faktor sperma (Anna, 2016).

\section{KESIMPULAN}

a. Terdapat hubungan pasca kontrasepsi hormonal dengan perolehan menstruasi $(p-$ 
value 0,003), dengan rata-rata perolehan menstruasi pada kontrasepsi kombinasi 2,031 bulan dan kontrasepsi progestin 8,187 bulan.

b. Terdapat hubungan pasca kontrasepsi hormonal dengan perolehan kehamilan ( $p$ value 0,011$)$, dengan rata-rata perolehan kehamilan pada kontrasepsi kombinasi 10 bulan dan kontrasepsi progestin 19,656 bulan.

\section{SARAN}

Perlu adanya Komunikasi Informasi dan Edukasi tentang kontrasepsi hormonal kepada masyarakat bahwa kontrasepsi ini tidak mengganggu kesuburan baik perolehan menstruasi ataupun perolehan kehamilan dengan media yang aplikatif.

\section{REFERENSI}

Adiesti, F. \& Wari, F.E., 2020. Hubungan kontrasepsi hormonal dengan siklus menstruasi. Jurnal Riset Kebidanan Indonesia, 4(1), pp.6-12. November 2020

Agustin, R., Andayani, A. \& Christiani, N., 2016. Perbedaan Pengembalian Kesuburan Pasca KB Suntik Di Desa Nyatnyono Ungaran Kabupaten Semarang. , (September). Available at: https://ppnijateng.org/wpcontent/uploads/2016/11/PROSIDINGMUSWIL-II-IPEMI-

JATENG_MAGELANG-17SEPTEMBER-2016.173-177.pdf. Diakses September 2020

Aldriana, Nana., A., 2017. Hubungan Lamanya Pemakaian Kontrasepsi Suntikan Dengan Kembalinya Kesuburan Pada Post Akseptor Kontrasepsi Suntikan Di Desa Pasir Utama Kecamatan Rambah Hilir. Jurnal Martenity and Neonatal, 2(4), pp.1-9. Diakses November 2020

Anna, L. K., 2016. "Susah Hamil Setelah Lepas KB, Kenapa?" Kompas. Available at: https://health.kompas.com/read/2016/11/ 25/080000923/susah.hamil.setelah.lepas. kb.kenapa.

Arikunto, S., 2010. Prosedur Penelitian Pendidikan Suatu Pendekatan Praktik. Jakarta: Rineka Cipta, p.274.

Blumenthal PD \& Edelman A., 2008. Hormonal contraception.

Obstet Gyneco;112(3):670-684. Available at: https://pubmed.ncbi.nlm.nih.gov/187576 $68 /$.
DIY BPS, 2020. Jumlah Pasangan Usia Subur dan Peserta KB Aktif Menurut Kabupaten di D.I.Y, DIY. Available at: https://yogyakarta.bps.go.id/static table/2020/8/07/144/JumlahPasanganUsia Subur-danpeserta-kb-aktifmenurutkabupaten-kota-di-d-iyogyakarta-2019-html. Diakses 14 Februari 2021.

Fahira, 2014. Faktor-faktor yang Berhubungan dengan Kebutuhan Keluarga Berencana yang Tidak Terpenuhi (Unmet Need) di Kecamatan Sipatana Kota Gorontalo, Jakarta. Available at: https://ejournal.unsrat.ac.id/index.php/jik mu/article/view/7454/7128. Diakses November 2020

Harni, A.J. \& Anita, A., 2017. Perbedaan Lama Waktu Kembali Hamil pada KB Suntik 1 Bulan dengan KB Suntik 3 Bulan di Wilayah Kerja Puskesmas Daya Murni Kabupaten Tulang Bawang Barat Lampung. Jurnal Kesehatan, 8(3), p.429. Diakses November 2020

Hartanto, H., 2010. Keluarga Berencana dan Kontrasepsi, Jakarta: Pustaka Sinar Harapan.

Noviawati., D., 2011. Panduan Lengkap Pelayanan KB Terkini, Yogyakarta: Nuha Medika.

Prawirohardjo, S., 2016. Ilmu Kebidanan Sarwono Prawirohardjo. Edisi $\mathrm{Ke}-4$. Jakarta: Yayasan Bina Pustaka Sarwono Prawirohardjo, pp.774-782.

Saifuddin, A. B. Affabdi, B., Baharudin, M \& Soekir, S., 2010. Buku Panduan Praktis Pelayanan Kontrasepsi, Jakarta: Yayasan Bina Pustaka.

Siswosudarmo, D., 2007. Teknologi Kontrasepsi, Yogyakarta: Medika fakultas Kedokteran UGM.

Sumadikarya, I. K., 2009. Rekomendasi Praktik Pilihan Untuk Penggunaan Kontrasepsi 2nd ed. A. W. Nugroho, ed., Jakarta: Published by the World Health Organization. Available at: https://apps.who.int/iris/bitstream/handle/ 10665/43097/9241562846_ind.pdf?seque nce $=5 \&$ is Allowed $=y$.

Whitaker, A. \& Gilliam, M., 2014. Contraception for adolescent and young adult women, Available at: https://link.springer.com/chapter/10.1007 /978-1-4614-6579-9_1. 